
em design

Capas de discos de vinil do rock brasileiro dos anos 1980; contextualização histórico cultural e análise visual Album covers of the 1980's Brazilian rock: historical cultural contextualization and visual analysis

\section{MORETTO, P.E.}

Graduado em Arquitetura e Urbanismo (1991) e Mestre em Estrutura Ambientais Urbanas (2004) pela FAU USP. Cursa Doutorado em Design na FAU USP (2018). Atua como designer gráfico, diretor de arte, pesquisador e curador, participando de importantes mostras de design.

Graduated in Architecture and Urbanism (1991) and Master's in Urban Environmental Structures (2004) from FAU USP. He is currently doing a Doctorate in Design at FAU USP (2018). Acts as a graphic designer, art director, researcher and curator, participating in relevant design exhibitions.

FARIAS, P. L.

Professora Associada no curso de Design da Universidade de São Paulo. Tem experiência em estudos de design, com foco em design gráfico e, mais especificamente, nos seguintes temas: tipografia, mídia digital, design de informação, histórico de design e design de tipos. Associate Professor of Design at the University of São Paulo. She has experience in design studies focusing on graphic design, more specifically on the following subjects: typography, digital media, information design, design history and type design.
No Brasil dos anos 1980, o chamado pop-rock tornou-se foco da cultura de massas, fazendo do disco de vinil um artefato emblemático dessa época. Este projeto parte da hipótese de que a mesma postura que caracterizava 0 rock brasileiro de então, com bandas experimentando diferentes sonoridades e misturando, a cada disco, influências de rock tradicional com música brasileira, punk rock, pós-punk, new wave e outros gêneros musicais, tenha caracterizado também o design das capas de disco, por meio da adoção de recursos como a colagem, a fragmentação, e o uso de diferentes referências visuais, postura característica do pós-modernismo. Como parte do estudo desta linguagem visual, apresenta-se uma seleção prévia de capas mais marcantes do rock brasileiro dos anos 1980, discutindo-se o processo e os critérios para considerálas capas representativas do período. Foram utilizados, para tanto, relatos históricos e teorias do design gráfico sobre linguagem, bem como observações do pesquisador a partir do contato direto com as peças gráficas estudadas.

Palavras-chave: Linguagem visual; Design gráfico; Rock brasileiro anos 1980; Capas de disco
In the 1980s, the so-called pop-rock became the focus of mass culture in Brazil, with vinyl disc becoming an emblematic graphic artifact of that time. This project starts from the hypothesis that the same attitude that characterized the Brazilian rock of the 1980's, with bands experimenting with different sounds and mixing influences of traditional rock with Brazilian music, punk rock, postpunk, new wave and other genres, has also characterized the design of album covers, with collage, fragmentation, and use of different visual references, all typical of postmodernism. As part of the study of their visual language, we present a selection of remarkable Brazilian rock album covers from the 1980s. The process and the criteria to consider them representative of the period are discussed using historical accounts and theories of graphic design on visual language, as well as the researcher's observations made from direct contact with the graphic pieces studied.

Keywords: Visual language; Graphic design; Brazilian rock 1980s; Album covers

contato

realização

ppgdesign_fauusp
5 dezembro 2018

cidade universitária, são paulo, sp 